\title{
From Integration to Exclusion: EU Composite Administration and Gaps in Judicial Accountability in the Authorisation of Pharmaceuticals
}

\author{
Sabrina RÖTTGER-WIRTZ* and Mariolina ELIANTONIO**
}

In the EU, pharmaceuticals are subject to a marketing authorisation requirement that, depending on the type of product concerned, can be obtained either centrally through a Commission decision with EU-wide effects or in the Member States, potentially subject to mutual recognition in composite authorisation procedures. These composite decision-making processes can nowadays be considered a standard way of administrative decision-making in the EU internal market. Yet, judicial supervision remains anchored in the separation of jurisdictions between the national and the EU level, and between national levels. This article explores the challenges posed to judicial review in the case of pharmaceutical marketing authorisations when European administrative composite structures are used.

\section{Setting the SCENE - COMPOSITE PROCEDURES AND JUdicial ReVIEW: LOST IN CO-OPERATION?}

In the EU, no medicinal product may be placed on the market without a marketing authorisation. ${ }^{1}$ Such a marketing authorisation may be obtained via four procedures, representing three different degrees of integrated administration: the national procedure; the Mutual Recognition Procedure; the Decentralised Procedure; and the Centralised Procedure. While purely national marketing authorisations in the individual Member States are still in existence, their applicability is limited. If a product is to be marketed in more than one Member State, the Mutual Recognition or the Decentralised Procedure

\footnotetext{
* Assistant Professor EU Law, Maastricht Centre for European Law (MCEL), Maastricht University; email: s.roettger-wirtz@maastrichtuniversity.nl

** Professor of European and Comparative Administrative Law and Procedure, Maastricht Centre for European Law (MCEL), Maastricht University.

1 Directive 2001/83/EC, OJ L 311, 28 November 2001, pp 67-128, Art 28, Regulation (EC) No 726/2004 OJ L 136, 30 April 2004, pp 1-33, Art 3(1). Norway, Iceland and Liechtenstein, which constitute the European Economic Area (EEA), also accepted the European pharmaceutical acquis and, wherever a Commission decision regarding a marketing authorisation is adopted, the three countries will take a corresponding decision allowing for the marketing of the product. EEA Joint Committee, Decision of the EEA Joint Committee N74/1999 of 28 May 1999 amending Protocol 37 and Annex II (technical regulations, standards, testing and certification) to the EEA Agreement, OJ L 284, 09.11.2000, pp 65-70.
} any medium, provided the original work is properly cited. 
have to be used. Finally, the Centralised Procedure provides for a decision-making process at the EU level, leading to a marketing authorisation valid throughout the Union granted by the European Commission.

While traditionally in EU administration, adhering to the framework of executive federalism, ${ }^{2}$ preference was given to indirect administration of EU law through the Member States, complemented by direct administration through EU bodies in accordance with the subsidiarity principle, the EU administrative law scholarship is increasingly uncovering and discussing an array of procedures which do not conform to this strict national and EU level dichotomy. ${ }^{3}$ This phenomenon has been termed "composite administration"4 and the ensuing procedures have been defined as " $(\ldots)$ procedures entailing the input of administrative actors from different jurisdictions, and in which the final decision, issued by a Member State or a EU authority, is based on procedures involving the more or less formalized input of the various participating authorities". 5 These procedures are furthermore characterised by a "decisional interdependence between national and EU authorities" $"$ in the sense that no step of the process can be taken unless all prior steps have been taken.

However, composite procedures challenge basic core principles of European administrative law, such as accountability, ${ }^{7}$ participation ${ }^{8}$ and judicial review. ${ }^{9}$ It is the latter on which we will focus in this article. Article 47 of the Charter promises the right to effective judicial protection, which is also recognised as general principle of EU law. ${ }^{10}$ In practice, however, while composite procedures nowadays are a common procedural path in the EU's composite (or integrated) ${ }^{11}$ administration, judicial protection has not followed suit and this right can fall between the cracks of

2 For a discussion of the development of EU executive federalism see R Schütze, "From Rome to Lisbon: "Executive Federalism" in the (new) European Union" (2010) 47 Common Market Law Review 1385.

3 E Schmidt-Aßmann and B Schöndorf-Haubold (eds), The European Composite Administration (Intersentia 2011); H Hofmann, et al, Administrative Law and Policy of the European Union (Oxford University Press 2011) p $406 \mathrm{ff}$; H Hofmann, "Decision-making in EU Administrative Law - the Problem of Composite Procedures" (2009) 61 Administrative Law Review 199; M Eliantonio, "Judicial Review in an Integrated Administration: the Case of 'Composite Procedures"' (2014) 7 Review of European Administrative Law 65. Della Cananea discussed the phenomenon under the term mixed administration: G Della Cananea, "The European Union's Mixed Administrative Proceedings" (2004) 68 Law \& Contemporary Problems 197.

4 Schmidt-Aßmann and Schöndorf-Haubold, supra, note 3.

5 Eliantonio, supra, note 3, p 68.

6 F Brito Bastos, "Derivative Illegality In European Composite Administrative Procedures" (2018) 55 Common Market Law Review 105.

7 Hofmann, supra, note 3.

8 J Mendes and C Eckes, "The right to be heard in composite administrative procedures: lost in between protection?" (2011) 36 European Law Review 651.

9 Hofmann, supra, note 3; Eliantonio, supra, note 3; A Türk, "Judicial review of integrated administration in the EU" in H Hofmann and A Türk (eds), Legal Challenges in EU Administrative Law: Towards an Integrated Administration (Edward Elgar 2009) p 218. The question of the competent court in composite procedures has recently been considered by the Court of Justice in Case C-219/17, Silvio Berlusconi and Fininvest v Banca d'Italia, ECLI:EU:C:2018:1023 concerning the Single Supervisory Mechanism.

10 Case C-279/09, DEB, ECLI:EU:C:2010:811; Case C-12/08, Mono Car Styling, ECLI:EU:C:2009:466. See further $\mathrm{S}$ Prechal and R Widdershoven, "Redefining the Relationship between 'Rewe-effectiveness' and Effective Judicial protection" (2011) 4 Review of European Administrative Law 31.

11 H Hofmann and A Türk, "The development of integrated administration in the EU and its consequences" (2007) 13 European Law Journal 253. 
administrative procedures, which increasingly do not conform to the direct/indirect administration division and its clear-cut jurisdiction division. ${ }^{12}$

These concerns regarding reviewability are not merely theoretical, but have already surfaced in the Decentralised Procedure for pharmaceutical marketing authorisations in the Astellas Pharma case, where the determination of reviewability and jurisdiction over an aspect of a marketing authorisation granted within the Decentralised Procedure raised complex questions. ${ }^{13}$ Although the marketing authorisation procedures in the pharmaceutical area have been studied, ${ }^{14}$ the impact of their composite nature on judicial reviewability has not been extensively analysed. ${ }^{15}$

This article examines the challenges composite procedures pose to judicial review in the marketing authorisation procedures for pharmaceuticals. These procedures provide an interesting case study, as the procedures can be characterised as multi-level, crosslevel and multi-institutional, depending on factors that the marketing authorisation applicant can only partially influence through his choice of procedure. In the area of pharmaceuticals, a curious procedural mix of national, mutual recognition and centralised European procedures co-exist. ${ }^{16}$ Moreover, procedures that might look like direct or indirect administration from the outside, upon closer examination reveal elements of vertical and horizontal administrative cooperation. Member States contribute their expertise and are part of the decision-making process even at the EU level stages, and in some procedures disagreement between the Member States can trigger an element of EU level arbitration. While this article is devoted to an analysis of the marketing authorisation procedures, it should also be noted that the enforcement of the pharmaceuticals regulatory framework through the Penalties Regulation is characterised by collaboration and exchange of information between the Commission, the European Medicines Agency, and national authorities, which leads to comparable challenges with regard to judicial review of the different procedural steps as the ones we raise in this article. ${ }^{17}$

12 Eliantonio, supra, note 3, p 96.

13 C-557/16, Astellas Pharma GmbH, ECLI:EU:C:2018:181. See also Opinion of AG Bobek in Case C-557/16, Astellas Pharma GmbH, ECLI:EU:C:2017:957. The case revolves around the data exclusivity period in the context of the decentralised procedure.

14 See eg J Feick, "Learning and interest accommodation in policy and institutional change: EC risk regulation in the pharmaceuticals sector" ESCR Centre for analysis of risk and regulation (CARR) Discussion Paper 25, January 2005; S Krapohl, Risk Regulation in the Single European Market - The Governance of Pharmaceuticals and Foodstuffs in the European Union (Palgrave 2008); G Permanand, EU Pharmaceutical Regulation: The Politics of Policy-Making (Manchester University Press 2006) p 49; S Shorthose, Guide to European Pharmaceutical Regulatory Law (Kluwer 2013) p 105 ff; M Manley and M Vickers (eds), Navigating European Pharmaceutical Law (Oxford University Press 2015) p $79 \mathrm{ff}$.

15 An exception is Collatz, which however dates from 1996 and does not reflect the current procedures and developments of Court jurisprudence: B Collatz, Die neuen europäischen Zulassungsverfahren für Arzneimittel (Editio-Cantor-Verlag 1996). For some remarks on judicial reviewability see Krapohl, supra, note 14, p 90.

16 See also Della Cananea, supra, note 3, pp 204-205.

17 For an analysis of the procedure and the hurdles to judicial accountability this can create see M Chamon and S Wirtz, "Complex procedures as hurdle to accountability: verticalization of pharmaceutical enforcement" in M Luchtman and M Scholten, Law Enforcement by EU Authorities - Political and Judicial Accountability in a Shared Legal Order (Edward Elgar 2017) p 141. Exemplary in this regard is a claim brought by Roche before the UK Court of Appeal against the UK Medicinal and Health Care Products Regulatory Agency (MHRA) which had inspected the Roche premises upon request of the EMA: $R$ (Roche) $v$ Secretary of State for Health [2014] EWHC 2256 (Admin), at [77]; $R$ (Roche) v Secretary of State for Health [2015] EWCA Civ 1311. 
This article proceeds as follows: firstly, the authorisation models will be examined, with special attention to the steps of the decision-making and their legal nature and consequences. Secondly, the reviewability of these steps will be analysed, and the gaps in judicial accountability will be highlighted. The article will conclude with some recommendations as to how the potential accountability gaps could be filled.

\section{MApping the MARKeting AUTHORISATION PROCEDURES FOR PHARMACEUTICALS IN THE EU: FOUR SHADES OF INTEGRATION}

As was pointed out earlier, pharmaceuticals can be authorised in a national, Mutual Recognition, Decentralised or Centralised Procedure. Which procedure is applicable depends on the where the product is meant to be marketed and also the category of pharmaceutical product in question. Apart from the purely national authorisation procedures, the other three procedures are composite at least to a certain degree, as the granting of a marketing authorisation leads to the close collaboration of EU and national actors in various steps of these procedures.

\section{The national procedure}

The national procedure is only applicable in cases where the product is to be marketed in only one Member State and does not fall into the categories of pharmaceuticals for which the Centralised Procedure is obligatory. ${ }^{18}$ In these procedures, an application for a marketing authorisation has to be submitted to the national competent authority of the Member State in question. The whole procedure is carried out within the administrative remit of that Member State and no input from other Member States or the EU is received. The national procedure is thus a very classic case of indirect administration and does not qualify as composite procedure. The national procedure may not be used where the product has already obtained a marketing authorisation in another Member State, as this would fall under the Mutual Recognition Procedure. Applications in several Member States simultaneously are also prohibited, as these cases fall under the Decentralised Procedure.

\section{The Mutual Recognition and Decentralised Procedures}

In principle, both the Mutual Recognition and the Decentralised Procedure are national procedures as well. ${ }^{19}$ The final decision on the marketing authorisation is adopted by each Member State in which an authorisation was requested. However, these procedures were introduced in order to prevent diverging decisions for the same product in various Member States. Due to the sensitive nature of pharmaceutical products for

\footnotetext{
18 Directive 2001/83/EC, OJ L 311, 28 November 2001, pp 67-128, Art 6 jo 17 and 18; Regulation (EC) No 726/2004 OJ L 136, 30 April 2004, pp 1-33, Art 3(1). For more information on the national procedure see: European Commission, "Notice to Applicants" Volume 2A - Procedures for marketing authorisation, Chapter 1 Marketing Authorisation, June 2018, available at <ec.europa.eu/health/sites/health/files/files/eudralex/vol-2/vol2a_chap1_en.pdf > (accessed 25 June 2019); Shorthose, supra, note 14, p 133 ff; Manley and Vickers, supra, note 14, pp 80-81.

19 For more information on the mutual recognition and decentralised procedure see European Commission, "Notice to Applicants", supra, note 18; Manley and Vickers, supra, note 14, p 81 ff; Shorthose, supra, note 14, p $127 \mathrm{ff}$.
} 
public health, the application of mutual recognition based on legal harmonisation without any proceduralised coordination between the Member States had proven futile. ${ }^{20}$ Therefore, in this case, the mutual recognition principle, as established in the Cassis de Dijon case, ${ }^{21}$ was embedded in a composite procedural framework.

The Mutual Recognition Procedure is the compulsory procedure for applying for a marketing authorisation in a Member State, when an authorisation has already been granted in another Member State. ${ }^{22}$ The Decentralised Procedure is triggered if no marketing authorisation has been granted by any Member State and the application is made simultaneously in several Member States. ${ }^{23}$ The procedures follow the same pattern, only the starting point is different, as under the Mutual Recognition Procedure one Member State has already granted a marketing authorisation, whereas in the Decentralised Procedure no marketing authorisation has been granted by a Member State.

As will be explained in detail below, three procedural phases can be distinguished: (i) a national phase with reference and concerned Member States; in case of disagreement between the Member States (ii) an intra-administrative phase in the Coordination Group for Mutual Recognition and Decentralised Procedures (CMDh); ${ }^{24}$ and, in case of disagreement in the CMDh (iii) a binding supra-national arbitration by the European Medicines Agency (EMA) and the Commission. ${ }^{25}$ Thus, depending on the level of agreement or disagreement between the Member States about a specific marketing authorisation, the information gathering and decision-making steps and actors involved in the procedure vary.

\section{a. The national phase}

If a marketing authorisation has already been obtained in one Member State (the so-called reference Member State, rMS), the marketing authorisation holder may ask for the recognition of this marketing authorisation in other Member States (the so-called concerned Member States, cMS), by applying for the Mutual Recognition Procedure (see Figure 1). The rMS will then update its assessment report and other required documentation and send it to the cMS within 90 days. ${ }^{26}$ After validation, ${ }^{27}$ the cMSs have 90 days to approve the assessment report and further documents provided. The mutual recognition principle that forms the basis of this procedure means that the cMSs must approve the report received from the rMS. ${ }^{28}$ Each cMS then has to grant the

\footnotetext{
20 See extensively J Feick, "Regulatory Europeanization, national autonomy and regulatory effectiveness: Marketing authorisation for pharmaceuticals", MPIfG discussion paper, No 02/6, available at <www.econstor.eu/bitstream/10419/ 43181/1/359456413.pdf > (accessed 25 June 2019).

21 C-120/78, Rewe-Zentral AG v Bundesmonopolverwaltung für Branntwein, ECLI:EU:C:1979:42 (Cassis de Dijon case).

22 Directive 2001/83/EC, OJ L 311, 28 November 2001, pp 67-128, Art 28(2).

23 ibid, Art 28(3).

24 The $\mathrm{CMDh}$ is responsible for medicinal products for human use, while a corresponding group CMDv is responsible for veterinary drugs.

25 Feick, supra, note 14, p $15 \mathrm{ff}$.

26 Directive 2001/83/EC, OJ L 311, 28 November 2001, pp 67-128, Art 28(3).

27 The cMSs will each validate the application, declaring that the required documentation was received and the fees paid.

28 See European Commission, "Notice to Applicants", supra, note 18, p 2.
} 


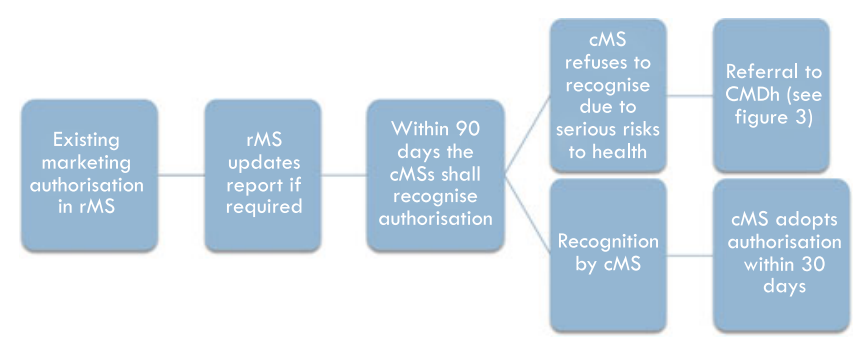

Figure 1: The national phase in the Mutual Recognition Procedure

marketing authorisation within 30 days. ${ }^{29} \mathrm{~A}$ cMS can only refuse approval based on potential serious risks to human health, which leads to a referral of the procedure to the CMDh. ${ }^{30}$

Thus, where no potential serious risks to human health are identified, the Mutual Recognition Procedure is composite in the sense that all cMSs have to take administrative decisions based on the information and decision provided by another Member State, but there is no structural "cooperation mechanism" foreseen between the rMS and the cMSs on the authorisation question. However, if one or more of the cMSs do have concerns regarding potential serious risks to human health, these are communicated and discussed between the Member States during a 90-day period the cMS(s) have to approve the assessment report of the rMS. ${ }^{31}$ In this case, either the issue is resolved within the 90-day deadline and the final decisions granting a marketing authorisation are adopted separately in all cMSs, or the procedure is referred to the CMDh.

The Decentralised Procedure facilitates the parallel application in several Member States, in cases where no marketing authorisation has been granted in any Member State (see Figure 2). The application will be submitted to all Member States for which the applicant desires authorisation, but the assessment is carried out by one reference Member State chosen by the applicant. Once all Member States have validated the dossier, the rMS has 120 days to draft an assessment report (assessment phase 1) ${ }^{32}$ During this time, the rMS will discuss the assessment with the cMSs, which means that if consensus is reached, the procedure can be closed and authorisations will be granted by the Member States. If consensus is not reached within the 120-day period, an additional period of up to 90 days may be granted for reaching consensus (assessment phase 2) ${ }^{33}$ If consensus is reached in assessment phase 2, the Member States will grant marketing authorisations within 30 days. $^{34}$

\footnotetext{
29 Directive 2001/83/EC, OJ L 311, 28 November 2001, pp 67-128, Art 28(5).

30 ibid, Art 29(1). For a definition of "potential serious risks to human health" see European Commission, "Guideline on the definition of a potential serious risk to public health in the context of Article 29(1) and (2) of Directive 2001/83/ EC', OJ C 133/5, 8.6.2006. Mutual recognition may not be refused on other grounds: see Case 452/06, Synthon, ECLI: EU:C:2008:565.

31 European Commission, Notice to Applicants Volume, supra, note 17, p 17. Potentially, a so-called break out session will be held in the CMDh to resolve disputes.

32 Directive 2001/83/EC, OJ L 311, 28 November 2001, pp 67-128, Art 28(3).

33 ibid, Art 28(4).

34 ibid, Art 28(5).
} 


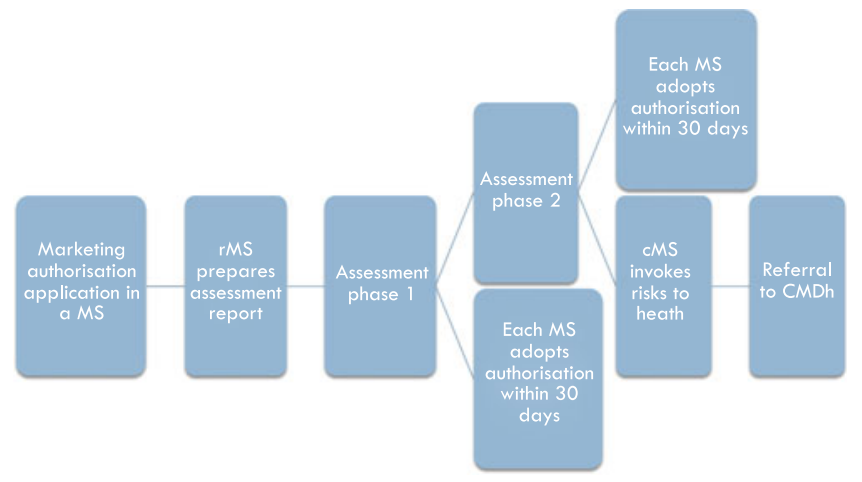

Figure 2: The national phase in the Decentralised Procedure

However, if consensus cannot be reached, because a cMS considers that there is a potential serious risk to human health, a referral of the procedure to the CMDh is made. ${ }^{35}$

The Decentralised Procedure, although the rMS is in the driving seat and carries out the assessment of the application, theoretically allows for an exchange of information and discussion of potential differences between the rMS and the cMSs. ${ }^{36}$ This stands in contrast to the Mutual Recognition Procedure, where the decision in the rMS has already been made at the start of the procedure and leaves less room for collaboration between the rMS and cMSs. The Decentralised Procedure is thus, as AG Bobek put it, a system based on "co-decision" logic. ${ }^{37}$

\section{b. The intra-administrative phase}

In both the Mutual Recognition Procedure and the Decentralised Procedure, if the rMS and cMSs can agree on the marketing authorisation application, the composite element of the procedure can only be seen in the horizontal exchanges between the competent authorities of the Member States where marketing authorisation is requested. However, where the rMS and cMSs cannot agree on whether to grant a marketing authorisation, the procedure is referred to the CMDh (see Figure 3). This referral is automatically initiated when at least one Member State does not approve the assessment report provided by the rMS within the 90 days deadline forseen in Article 28(4) of Directive 2001/83. ${ }^{38}$

\footnotetext{
35 Directive 2001/83/EC, OJ L 311, 28 November 2001, pp 67-128, Art 29(1). Only a positive assessment of the rMS will be referred to the CMDh. If the rMS concludes that no authorisation should be granted, even if a cMSs want to approve the product, the procedure will end with a negative decision of the rMS and all cMSs are obliged to take a negative decision. See CMDh, "Questions and Answers" CMDh Referrals, CMDh/167/2005, Rev 11 February 2016, available at <www.hma.eu/fileadmin/dateien/Human_Medicines/CMD_h_/Questions_Answers/CMDh_ 167_2005_Rev11_2016_02_clean.pdf >.

36 European Commission, "Notice to Applicants", supra, note 18, pp 25-27.

37 Opinion of AG Bobek in Astellas Pharma Gmbh, supra, note 13, para 70.

38 Directive 2001/83/EC, OJ L 311, 28 November 2001, pp 67-128, Art 29(1).
} 
The CMDh is composed of one representative per Member State, as well as the Commission and the EMA as observers. ${ }^{39}$ It is intended to provide a forum for deliberation to facilitate mutual recognition, and it will try to reach a consensual agreement for disputes between the rMS and cMSs on potential serious risks to human health within 60 days. ${ }^{40}$ It is not part of the European Medicines Agency; however, the Secretariat to the CMDh is provided by the EMA and the monthly meetings take place at the EMA premises.

The CMDh referral does not end with a formal opinion or decision of the CMDh, but Article 28(3) of Directive 2001/83/EC states that: "If ( . . . ) the Member States reach an agreement, the reference Member State shall record the agreement, close the procedure and inform the applicant accordingly". If consensus on the authorisation is reached, the competent authorities in the cMSs will grant national marketing authorisations within 30 days. $^{41}$ If no consensus is reached within the allocated time, the procedure is referred to the EMA for arbitration, ${ }^{42}$ which marks the beginning of the supra-national arbitration phase.

\section{c. The binding supra-national arbitration phase}

If the Member States cannot reach consensus within the CMDh, the arbitration takes place at the EU level (see Figure 3). Within the EMA, the Committee for Medicinal Products for Human Use (CHMP) will from an opinion on the marketing authorisation application. ${ }^{43}$ The CHMP is the agency's main scientific committee for human medicinal products and is composed of one chair, elected by the serving CHMP members, as well as one member plus alternate for each Member State, and one representative (plus alternate) for Iceland and Norway. ${ }^{44}$ Thus, although the EMA is an EU body, the Committee that carries out the assessment is composed of experts appointed by the Member States, usually belonging to the national competent authorities. ${ }^{45}$ The CHMP will adopt its opinion within 60 days. ${ }^{46}$ In case of a negative opinion, the applicant will be informed before the adoption of the opinion and has the chance to request a re-examination. ${ }^{47}$ The final EMA opinion is sent to the Commission, which prepares a draft decision. The Commission's draft decision is subject to comitology within the examination procedure laid down in Article 5 of

\footnotetext{
39 European Commission, "Notice to Applicants", supra, note 18, p 6. Directive 2001/83/EC, OJ L 311, 28 November 2001, pp 67-128, Art 27.

40 Directive 2001/83/EC, OJ L 311, 28 November 2001, pp 67-128, Art 29(3).

41 ibid, Art 29(3) jo 28(5).

42 ibid, Art 29 (4).

43 ibid, Art 32 (1).

44 Regulation (EC) No 726/2004 OJ L 136, 30 April 2004, pp 1-33, Art 61(1).

45 The EMA, for this reason, has been characterised as a network: R Dehousse, "Regulation by Networks in the European Community: the Role of European Agencies" (1997) 4 Journal of European Public Policy 246; A Spina, "The Regulation of Pharmaceuticals Beyond the State: EU and Global Administrative Systems" in E Chiti and B Mattarella (eds), Global Administrative Law and EU Administrative Law (Springer 2011) p 249.

46 Directive 2001/83/EC, OJ L 311, 28 November 2001, pp 67-128, Art 32(1).

47 ibid, Art 32(4).
} 


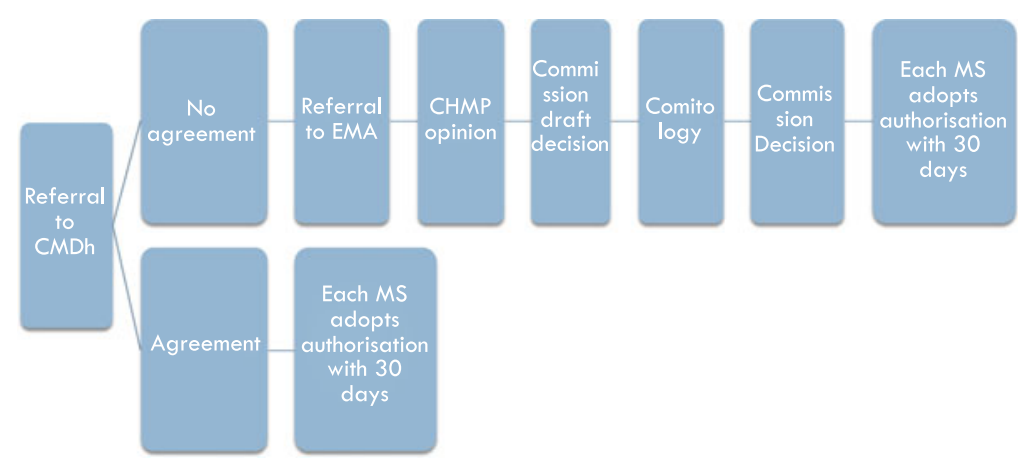

Figure 3: The intra-administrative phase and the binding supra-national arbitration phase

Regulation (EU) 182/2011, ${ }^{48}$ in which the Standing Committee on Medicinal Products for Human Use, consisting of Member State representatives, votes on the adoption of this draft decision by qualified majority. ${ }^{49}$

After the comitology procedure, the Commission adopts the final decision. ${ }^{50}$ This Commission Implementing Decision is addressed to all Member States and those Member States involved in the Mutual Recognition or Decentralised Procedure are required to follow it. ${ }^{51}$ Thus, after the Commission decision, the national authorities have 30 days to comply with the Commission decision, and either adopt or refuse a marketing authorisation through a decision addressed to the applicant. ${ }^{52}$

\section{The Centralised Procedure}

The Centralised Procedure leads to a marketing authorisation that permits the marketing of a medicinal product in the whole EU (see Figure 4). ${ }^{53}$ The procedure is compulsory for certain innovative products, ${ }^{54}$ and can be optionally chosen for other products. ${ }^{55}$

In the Centralised Procedure, the application is submitted to the EMA. ${ }^{56}$ Within the EMA, the Committee for Medicinal Products for Human Use (CHMP) carries out the benefit/risk analysis and provides a scientific opinion on the marketing authorisation of the product in question. The CHMP appoints one of its members to act as rapporteur, taking the lead in preparing the scientific assessment of the application and the drawing up of a report. ${ }^{57}$ Moreover, a co-rapporteur is nominated who either

\footnotetext{
48 Regulation (EU) No 182/2011 of the European Parliament and of the Council of 16 February 2011 laying down the rules and general principles concerning mechanisms for control by Member States of the Commission's exercise of implementing powers, OJ L 55, 28 February 2011, pp 13-18.

49 For more information see: European Commission, "Notice to Applicants", supra, note 18.

50 Directive 2001/83/EC, OJ L 311, 28 November 2001, pp 67-128, Arts 33 and 34.

51 ibid, Art 34(3); European Commission, "Notice to Applicants”, supra note 18, p 7.

52 Directive 2001/83/EC, OJ L 311, 28 November 2001, pp 67-128, Art 34(3).

53 For a discussion of the centralised procedure see Manley and Vickers, supra, note 14, p $89 \mathrm{ff}$; Shorthose, supra, note 14, p $117 \mathrm{ff}$.

54 Regulation (EC) No 726/2004 OJ L 136, 30 April 2004, pp 1-33, Art 3(1) jo Annex.

55 ibid, Art 3(2).

56 ibid, Art 4.

57 Committee for Medicinal Products for Human Use, Rules of Procedure, EMEA/45110/2007, Art 6.
} 


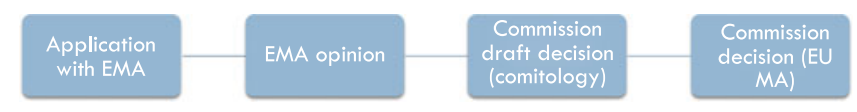

Figure 4: The Centralised Procedure

will prepare a critical assessment of the report drawn up by the rapporteur, or will write their own assessment report, depending on the choice of the Committee. ${ }^{58}$ After the assessment the CHMP adopts a favourable or unfavourable opinion. ${ }^{59}$ The decision-making usually takes place by consensus, but requires at least absolute majority of the Committee members. ${ }^{60}$ In case of an unfavourable opinion, the applicant may request a re-examination. ${ }^{61}$

The final EMA opinion is sent to the Commission, which adopts a draft decision within 15 days, ${ }^{62}$ subject to comitology. Although the EMA opinion is only of advisory nature, it is notable that the Commission usually follows the CHMP opinion. ${ }^{63}$ A positive decision adopted by the Commission, in the form of a Commission Implementing Decision, grants a marketing authorisation decision addressed to the applicant, being valid within the whole Union for five years, meaning that the decision is binding upon the Member States. $^{64}$

At first sight, this procedure does not seem composite at all, but very much an example of direct administration. The whole process, including the final decision, is carried out at the EU level through the European Medicines Agency and the European Commission. However, upon close examination it becomes clear that the CHMP is composed of members nominated by the Member States, the overwhelming majority of whom are representatives of national competent authorities. The rapporteur and co-rapporteur carrying out the scientific assessment which forms the basis of the EMA opinion rely on the administrative structures of their national competent authorities for their scientific expert assessment. Thus, although the CHMP opinion is a measure of the EMA, its coming into being heavily depends on expertise and information provided by national competent authorities. Moreover, also in the comitology stage, representatives of the Member States take part in the process. Thus, the centralised procedure is also a composite procedure. $^{65}$

\footnotetext{
58 ibid, Art 6(3).

59 Regulation (EC) No 726/2004 OJ L 136, 30 April 2004, pp 1-33, Arts 5(2) and 6(3). Additionally, Regulation (EC) No 726/2004 provides for the possibility to grant a conditional marketing authorisation (Art 14(7)) which is reviewed annually, and a marketing authorisation under exceptional circumstances (Art 14(8)), which contains certain obligations with regard to the safety of the product.

60 Committee for Medicinal Products for Human Use, Rules of Procedure, EMEA/45110/2007, Art 8.

61 ibid, Art 9(1)-(3).

62 ibid, Art 10.

63 See also T Gehring and S Krapohl, "Supranational Regulatory Agencies between Independence and Control. The EMEA and the Authorisation of Pharmaceuticals in the European Single Market" (2007) 14 Journal of European Public Policy 208, at p 216; Feick, supra, note 14, p 14.

64 Regulation (EC) No 726/2004, OJ L 136, 30 April 2004, pp 1-33, Art 13-14.

65 See also Eliantonio, supra, note 3, p 75.
} 


\section{GAPS OF JUdicial PROTECTION IN THE COMPOSITE PROCEDURES USED FOR}

\section{MARKETING AUTHORISATION OF PHARMACEUTICALS}

The section above has shown that the procedures to be followed in the marketing authorisation of pharmaceuticals are prime examples of composite procedures, involving a variety of actors, actions and levels of governance. While administrative decision-making procedures are increasingly integrated, however, judicial review still remains firmly anchored to a dualistic vision, whereby the judicial level competent in shared administrative procedures corresponds to the administrative level that has adopted the act under challenge. The gaps this causes in the judicial review of the three composite procedures discussed will be examined below. The article will not be concerned with all possible aspects of judicial review in the authorisation of pharmaceuticals, but will only examine the question of access to the court and reviewability of all steps of the decision-making process where gaps in judicial protection have been identified by the authors.

We will not only examine the access to court for marketing authorisation applicants, but where appropriate will also take into account acccess to court for competitors or civil society organisations who might want to oppose an authorisation. Consumer associations might want to go to court when they disagree about the safety of the marketed product. Admittedly, in the Olivieri case, the Court has established, in the context of a Centralised Procedure, that the marketing authorisation procedure is entirely bilateral between the applicant and the assessing authorities. ${ }^{66}$ Nevertheless, and despite the lack of any general right of participation or intervention of public interest organisations in a marketing authorisation procedure, the idea of a "Community based on the rule of law" 67 and the right to effective judicial protection ${ }^{68}$ require that actions of EU public authorities can be subject to judicial scrutiny, not only by the addressees, but also by interested third parties or associations promoting general and collective interests.

For competitors, it might be argued, first of all, that competitors could also exercise a "public interest" role as watchdogs where they litigate against a presumably unsafe product; ${ }^{69}$ secondly, and specifically in case of marketing authorisations of pharmaceuticals, the legislative framework allows to refer to and build upon the marketing authorisation of another product, eg to authorise a generic product. For competitors it might therefore be important to be able to challenge a marketing authorisation because they might rely on marketing authorisation dossier of an already authorised product to authorise their (generic) product. ${ }^{70}$ Moreover, the marketing authorisation decision determines how long a pharmaceutical is

\footnotetext{
66 T-326/99, Fern Olivieri v Commission and EMEA, ECLI:EU:T:2003:351, paras 93-95.

67 Case 294/84, Parti écologiste “Les Verts” v European Parliament, ECLI:EU:C:1986:166.

68 Art 47 of Charter of Fundamental Rights of the European Union.

69 In the Olainfarm case a challenge brought by a competitor required the Court to examine whether a generic product can be authorised by reference to a product which has been authorised on well-established use basis, or whether this would provide too little safety and efficacy information. The Court found in favour of the generic authorisation: Case C-104/13, Olainfarm, ECLI:EU:C:2014:2316. Not related to a safety concern but to unfair commercial practices, the generics company Teva alerted the French competition authority to unfair commercial practices of Sanofi-Aventis, which actively discouraged the prescription of generics for their clopidogrel product Plavix: see $<w w w$.autoritedelaconcurrence.fr/user/standard.php?id_rub=483\&id_article=2091 $>$.

70 Directive 2001/83/EC, OJ L 311, 28 November 2001, pp 67-128, Art 10.
} 
protected from competition of generic producers, which can be the object of dispute between originator and generic producers as exemplified in the recent Astellas Pharma case. $^{71}$

\section{The Mutual Recognition and Decentralised Procedures}

\section{a. Scenario 1: consensus between Member States and marketing authorisation is granted}

If, in the Mutual Recognition Procedure or in the Decentralised Procedure, no disagreement between Member States arises, the marketing authorisation is granted in the form of a national administrative decision. In these cases, a competitor or a civil society organisation might want to challenge the authorisation, arguing that the scientific basis for the authorisation was flawed.

In accordance with the strict separation of jurisdictions, a challenge against the marketing authorisation can only be brought before the national court of the state which has adopted the respective decision, thus the rMS or a cMS. However, if it is argued that, for example, the report submitted by the rMS is flawed, the court of the cMS will not be able to assess the report submitted by the rMS, because it is a measure stemming from a different legal system. As AG Bobek put in a recent opinion, "the territorial nature of each of the marketing authorisations and the necessary correlating territorial nature of judicial review" will create obstacles to the control of acts or actions originating in another jurisdiction. ${ }^{72}$ As there is no "horizontal preliminary reference", the only alternative for the applicant is to challenge the report of the rMS before the competent national court of the rMS. In principle this possibility is open to applicants, depending on national rules of standing, but the report will hardly be considered a reviewable act, as it is only an intermediate step in the decision-making process. This problem has again been highlighted by AG Bobek: when discussing the Decentralised Procedure, he considered the nature of the report in question and concluded that "[I]n a number of Member States, it is quite likely that that report may be classified as a preparatory act and thus not amenable to judicial review". ${ }^{73}$

The Borelli ruling, in which the CJEU held that a rule of national law that prevented legal action from being taken against a mere preparatory act would be in violation of the right of access to justice, ${ }^{74}$ does not seem to open any possibility for judicial review in the case at stake. This is because the duty of national courts to review a national preparatory measure has been grounded by the court in the fact that this measure "is binding on the Community decision-taking authority and therefore determines the terms of the

\footnotetext{
71 See C-557/16, Astellas Pharma GmbH, ECLI:EU:C:2018:181, which exemplifies this situation.

72 Opinion of AG Bobek in Astellas Pharma Gmbh, supra, note 13, para 92.

73 ibid, para 90.

74 Case C-97/91, Oleificio Borelli SpA v Commission, ECLI:EU:C:1992:491. The same position has been more recently reiterated in Case C-562/12, Liivimaa Lihaveis MTÜ v Eesti-Laüti programmi 2007-2013 Seirekomitee, ECLI:EU:C:2014:2229.
} 
Community decision to be adopted", ${ }^{75}$ hence a situation in which there is no discretion for the authority issuing the final decision. ${ }^{76}$

In conclusion, in court of a cMS it is possible to challenge the authorisation of that cMS but not the report or authorisation of the rMS, as the "act" originates in different legal system; in an rMS, it is in principle not possible to challenge the report due to its preparatory nature, unless, in (an unlikely) application of the Borelli ruling, the court was ready to disregard national procedural rules barring such a claim.

It should be stressed that, while this gap of judicial accountability arises equally in Mutual Recognition and in Decentralised Procedures, it is in the latter type of procedures that the gap is more worrisome. This is because, while in the Mutual Recognition Procedure there is a prior authorisation, and the cooperation between Member States is limited to the sharing of the updated assessment report from the rMS to the cMS, in the Decentralised Procedure, the sharing of risk-related information forms much more of a "web" of relations between Member States. As AG Bobek recently put it, "[I]n a Decentralised Procedure, all of the Member States participate in the elaboration of their decision at the same time. To put it metaphorically, cooking with friends is not the same as sharing meals that have already been prepared" ${ }^{77}$ In such a situation, apart from the gap highlighted above, it may also be much more complex for a potential applicant to even be able to re-trace the source of a certain piece of information which led to the rejection of the marketing authorisation.

\section{b. Scenario 2: no consensus between Member States (a cMS considers that there are} serious risks to health), referral to the CMDh, which reaches an agreement (leading either to the denial or the granting of a marketing authorisation)

The question which arises in such a situation is, first of all, whether a potential applicant could challenge a referral to the CMDh; secondly, whether the actions themselves of the CMDh could be attacked; and, thirdly, whether the final measure of denial or granting of the marketing authorisation could be challenged.

Starting from the last step, while an applicant could challenge before a national court the denial or granting of the marketing authorisation, it is doubtful whether the national court would be able to effectively review this measure if the applicant claims that the measure is based on a flawed course of action at the level of the CMDh (eg some procedural error was made in the CMDh procedure or the CMDh disregarded some rules of the applicable legislative framework). This is because the CMDh is not a national administrative authority whose acts can be reviewed by the national courts.

The actions of the CMDh are therefore difficult to review before a national court. So can an applicant then challenge the actions of the CMDh before the European courts pursuant to Article 263 TFEU? A hurdle seems to be the so-called "authorship criterion", as only acts of the EU institutions, and "acts of bodies, offices or agencies

\footnotetext{
75 Case C-97/91, Oleificio Borelli SpA v Commission, para 10.

76 See further on this F Brito Bastos, "The Borelli Doctrine Revisited: Three Issues of Coherence in a Landmark Ruling for EU Administrative Justice” (2015) 8(2) Review of European Administrative Law 269.

77 Opinion of AG Bobek in Astellas Pharma Gmbh, supra, note 13, para 49.
} 
of the Union" may be challenged under Article 263. The CMDh is a body composed of national representatives which therefore does not seem to meet these criteria. Hence, it does not seem possible to directly challenge the actions of the CMDh in an annulment action either.

However, in light of recent jurisprudential developments, it could at least be argued that the CJEU might have jurisdiction to indirectly review the actions of the CMDh in preliminary questions of validity under Article 267 TFEU. In James Elliott, the CJEU held that it had jurisdiction in preliminary questions over the acts of the bodies which are created "in implementation of EU law". ${ }^{78}$ As the CMDh is a body created in implementation of secondary EU law, there is potential to argue that preliminary questions of validity over its actions will be available.

A different question, apart from the nature of the body in question, is linked to the nature of the actions of the CMDh. Indeed, as mentioned above, the referral procedure does not end with a formal opinion or decision of the CMDh, but Article 28(3) of Directive 2001/83/EC merely states that: "If ( . . . ) the Member States reach an agreement, the reference Member State shall record the agreement, close the procedure and inform the applicant accordingly". It can be asked if, in light of this provision, there is an actual measure or action to be challenged in the first place. It may be a case of les than careful drafting, but Article 28(3) seems to suggest that the $\mathrm{CMDh}$ is not actually capable of carrying out actions, which remain imputable to the Member States acting within a collective body.

The last question linked to the CMDh is whether an applicant could challenge a referral to the CMDh, which "moves" the Mutual Recognition and Decentralised Procedures from the national level to the intra-administrative level. Indeed, a market operator might have an interest in keeping the authorisation procedure at the national level because of the delays (and related loss of profit) involved, but also because, as shown above, the actions of the $\mathrm{CMDh}$ can hardly be controlled and the operator does not know how the CMDh will decide. In this situation, the operator is faced with a gap of judicial protection because it cannot oppose the referral to the CMDh. This is because the referral is a procedural step, which is automatically triggered, where a cMS does not agree with the positive assessment report of the rMS. The actual effect on the applicant's legal sphere will only be produced at the end of the process when the decision on the marketing authorisation is issued.

This conclusion is supported by a recent order of the General Court concerning another type of referral in the same field of pharmaceuticals. ${ }^{79}$ In this case the referral was a so-called "Union interest referral" pursuant Article 31 of Directive 2001/83, which refers a question to the relevant EMA Committee, the CHMP. ${ }^{80}$ In this type of referral the procedure is initiated either by a Member State, the Commission or a marketing authorisation holder, due to concerns relating to the quality, safety or efficacy of a medicine. The company alleged that the conditions for launching the review

\footnotetext{
78 Case C-613/14, James Elliott Construction, EU:C:2016:821, para 47 and case law cited therein.

79 Case T-295/16, Symbioflor v EMA, ECLI:EU:T:2017:147.

80 Directive 2001/83/EC of the European Parliament and of the Council of 6 November 2001 on the Community code relating to medicinal products for human use [2001] OJ L 311/67.
} 
procedure were not fulfilled. The General Court dismissed the action as inadmissible, considering that, according to constant case law, ${ }^{81}$ the initiation of a procedure does not affect the legal position of the company. Moreover, according to the court, within a procedure consisting of several steps, when the final decision is challenged before the courts, the interim steps can also be attacked. This statement is line with the CJEU's general approach to "derivative illegality" 82 at EU level, on the basis of which "any unlawful features vitiating ... a preparatory act must be relied on in an action directed against the definitive act for which it represents a preparatory step". ${ }^{83}$ Such derivative illegalilty is exemplified by a recent ruling in an appeals case brought by the Dr August Wolff GmbH against a Commission Implementing Decision that was taken in an Article 31 referral procedure. ${ }^{84}$ The Court annulled the Implementing Decision, based on its finding that the rapporteur appointed in the EMA CHMP for the referral was not sufficently impartial.

The General Court, taking a rather legalistic approach, considered therefore that only measures creating "binding legal effects" capable of modifying the legal sphere of the applicant, may be subject to an annulment action. Furthermore, the Court suggested that, for all other prejudicial effects created by these intermediate acts, the action for Union liability could be launched once the illegality of the final decision of the process was found.

If the Court denied the reviewablility of a referral procedure that has to be specifically triggered, it can be inferred that it is even less likely to admit the reviewability of a referral in the Mutual Recognition and Decentralised Procedure, which consitutes a "normal" procedural step in case of disagreement between the Member States and is not triggered by a dedicated act of a Member State. In conclusion, when the intraadministrative phase of the Mutual Recognition and the Decentralised Procedures is activated, an applicant cannot object to the referral and can only indirectly (if ever) challenge the actions of the CDMh which are the basis of the final decision on the marketing authorisation.

\section{c. Scenario 3: no consensus between Member States (a cMS considers that there are serious risks to health), referral to the CMDh, which does not reach an agreement (leading to a referral to EMA and a final Commission decision)}

Subsection $b$ above has examined the gaps of judicial protection in respect of situations in which the $\mathrm{CMDh}$ is able to reach consensus and a final national measure concludes the process. However, it is also possible that no consensus is reached by the CMDh on whether an authorisation can be granted, and the matter reaches the supra-national arbitration phase. The absence of consensus and with that the referral itself to the EMA are not open to challenge, for the same reasons already discussed in the referral step of Scenario 2, even though it entails a loss of time and possible financial loss for the applicant.

\footnotetext{
81 Case 60/81, IBM v Commission, ECLI:EU:C:1981:264.

82 The expression is borrowed from Brito Bastos, supra, note 6, p 101-134.

83 Case 60/81, IBM v Commission, ECLI:EU:C:1981:264, para 12.

84 Case C-680/16 P, Dr August Wolff GmbH v Commission, ECLI:EU:C:2019:257.
} 
Neither can the opinion of the EMA adopted during the referral be the subject matter of a direct action, again because of its preparatory nature and consequent incapability of directly affecting an applicant's legal sphere. However, the opinion will be reviewed by the European courts in a direct action against the final Commission decision. This is confirmed by the Olivieri case, in which the Court of Justice stated that the content of an EMA's opinion, and also that of the assessment reports upon which it is based, are an integral part of the statement of reasons for the final decision. ${ }^{85}$

The final step of the process is a Commission Implementing Decision addressed to the Member States, which certainly constitutes a reviewable act for the purposes of an action for annulment. However, competitors and consumer associations (in case the decision is positive) will be faced with considerable difficulties proving that they have standing in such a direct action. This is because the Commission Implementing Decision may not be qualified as a regulatory measure, because, although it is not taken with a legislative procedure, it is not of general application. The latter concept, according to settled case law of the Court of Justice, refers to situations in which an act "applies to objectively determined situations and produces legal effects with respect to categories of persons envisaged in a general and abstract manner". ${ }^{86}$ In the case at stake, the Commission Implementing Decision applies to specific marketing authorisations (hence objectively determined situations), but only produces legal effects on the Member States and, through the final national authorisation, the marketing authorisation applicant. On this basis, the measure cannot profit from the more relaxed standing requirements for regulatory measures introduced by the Lisbon Treaty in Article 263(4) TFEU. Moreover, the Commission Implementing Decision also entails implementing measures (in the form of a final national measure granting or denying the marketing authorisation). This implies that the applicants need to meet the "general" standing requirements and, consequently, to prove individual and direct concern.

According to the orthodox interpretation of the concept of individual concern, an applicant would have to prove that he belongs to a closed class and is affected by the measure in the same way as the addressee. ${ }^{87}$ This is possible for the marketing authorisation applicant, given that he is concerned by the measure in a different way than other market participants, as he is the initiator of the marketing authorisation procedure and, through the composition of the dossier, influences its content. Furthermore, the marketing authorisation applicant will also be able to prove direct concern as the final national measure "directly affect[s] the legal situation of the individual and leave[s] no discretion to the addressees of that measure who are entrusted with the task of implementing it, such implementation being purely automatic and resulting from Community rules without the application of other intermediate rules". 88

\footnotetext{
85 Case T-326/99, Fern Olivieri v Commission and EMEA, ECLI:EU:T:2003:351, para 55. See also the example of Dr August Wolff GmbH v Commission, supra, note 84.

86 Joined Cases C-622/16P to C-624/26P, Scuola Elementare Maria Montessori Srl v European Commission, ECLI: EU:C:2018:873, para 29.

87 Case 25/62, Plaumann \& Co v Commission ECLI:EU:C:1963:17.

88 Case C-386/96 P, Société Louis Dreyfus \& Cie v Commission, ECLI:EU:C:1998:193, para 43.
} 
However, proving individual concern is improbable at best for competitors, seeing that individual concern has not been recognised in situations concerning "a commercial activity which may at any time be practised by any person". ${ }^{89}$ As far as associations are concerned, it is settled case law that these actions are only admissible in three situations: $^{90}$ (a) when a legal provision grants procedural rights to these associations; ${ }^{91}$ (b) where every single member of the association would be directly and individually concerned $;{ }^{92}$ and (c) where the association's interests, and especially its position as a negotiator, is affected by the measure. ${ }^{93}$ Considering that none of these conditions are met in the case of marketing authorisations for pharmaceuticals, the competitor and the association are not likely to be able to prove individual concern. The only possibility for them, therefore, is to wait until there is a final decision by a national authority, bring a claim against this measure, and ask the national court to ask a preliminary question of validity under Article 267 TFEU.

In conclusion, in the supra-national arbitration phase, the referral of the procedure to EMA cannot be challenged, while EMA's opinion and the surrounding input could be challenged together with the final Commission Implementing Decision. The Commission Implementing Decision can be challenged by the applicant via an action for annulment - a route which is however closed for competitors and civil society organisations. The latter groups of applicant may only challenge the Commission Implementing Decision indirectly through a preliminary question of validity against the final national measure concluding the decision-making process.

\section{Centralised Procedure}

As mentioned above, the Centralised Procedure starts with a submission of an application to the EMA and then it follows the same steps of the supranational arbitration phase (in terms of the engagement of EMA and the relevant comitology committee), except that there is no final national measure at the end of decision-making process, but the marketing authorisation (or its denial) is contained in a Commission Implementing Decision addressed to the applicant.

89 ibid.

90 Case C-321/95 P, Stichting Greenpeace Council (Greenpeace International) and Others v Commission, ECLI:EU: C:1998:153; Case T-122/96, Federazione nazionale del commercio oleario (Federolio) v Commission, ECLI:EU: $\mathrm{T}: 1997: 142$.

91 Case 191/82, EEC Seed Crushers' and Oil Processors' Federation (FEDIOL) v Commission, ECLI:EU: C:1983:259; Case T-12/93, Comité Central d'Entreprise de la Société Anonyme Vittel and Comité d'Etablissement de Pierval and Fédération Générale Agroalimentaire v Commission, ECLI:EU:T:1995:78.

92 Joined Cases T-447/93, T-448/93 and T-449/93, Associazione Italiana Tecnico Economica del Cemento and British Cement Association and Blue Circle Industries plc and Castle Cement Ltd and The Rugby Goup plc and Titan Cement Company SA v Commission, ECLI:EU:T:1996:174; Case T-380/94, Association internationale des utilisateurs de fils de filaments artificiels et synthétiques et de soie naturelle (AIUFFASS) and Apparel, Knitting \& Textiles Alliance $(A K T) v$ Commission, ECLI:EU:T:1996:195; Case T-229/02, Osman Ocalan acting on behalf of Kurdistan Workers' Party (PKK) v Council of the European Union, ECLI:EU:T:2008:87.

93 Joined Cases 67/85 R, 68/85 R and 70/85 R, Kwekerij Gebroeders van der Kooy BV and others v Commission, ECLI:EU:C:1985:173; Case T-84/01, Association contre l'horaire d'été (ACHE) v Council of the European Union and European Parliament, ECLI:EU:T:2002:5. 
With regard to the reviewability of EMA's opinion, the same considerations made above apply. With regard to the final Commission decision in the Centralised Procedure, it should initially be pointed out that there are two main differences between the measure issued by the Commission in the Centralised Procedure and the Commission's engagement in the Mutual Recognition and Decentralised Procedures. First, in terms of the addressees of the Commission's action, in the first case the decision is addressed to the Member States, while in the second it is addressed to the applicant. Secondly, while in the first case the Commission decision is itself a step in the decision-making process which is concluded at the national level, in the second case the Commission Implementing Decision is the final step in the decision-making procedure.

However, these two differences have no impact for the purposes of the rules on standing. First of all, as regards the marketing authorisation applicant, the fact that the Commission Implementing Decision in the centralised procedure is addressed to the operator means that he will be able to challenge the measure under an action for annulment. Secondly, with regard to competitors and associations, as in the case examined above, this Commission Implementing Decision cannot be qualified as a measure of general application, and hence is not a regulatory act for the purposes of Article 263 TFEU. As consequence, competitors and associations do need to prove individual and direct concern, which, for the reasons highlighted above, seems improbable at best.

In conclusion, in cases concerning the Centralised Procedure, the applicant will be able to challenge the final Commission Implementing Decision, and, through that, also EMA's opinion, while competitors and associations will have a hard time proving individual concern.

\section{Conclusion And POSSIBLE SOlutions}

The analysis above has shown that, in the area of pharmaceuticals, the complex authorisation routes, which form a curious mix of direct, indirect and composite administration, mean that the judicial protection that is granted is heavily dependent on the applicable procedure and the question of the degree to which Member States can agree upon a positive evaluation. First of all, the choice of procedure is very much dictated by the nature of the product and targeted markets. Then, if the mutual recognition or decentralised procedural route is chosen, for one and the same product and the same type of decision requested (a marketing authorisation), the judicial review possibilities depend on the ability of the Member States to find consensus during the procedure, which is beyond the control of the marketing authorisation applicant. This roulette wheel of access to judicial review is even more pronounced for competitors and public interest organisations, who are mere bystanders during the procedure.

Furthermore, the analysis above has revealed that gaps in judicial reviewability almost only arises in cases of "truly" composite procedures, while in the national procedure no problem of judicial protection arises due to the absence of multi-level activity. Also in the 
Centralised Procedure, the only gap identified is the lack of standing of competitors and associations, but this is caused by the Plaumann doctrine and the restrictive interpretation by the CJEU of the notion of "individual concern" rather than the composite nature of the procedure.

Thirdly, it has been shown that, in "truly" composite procedures (namely the Decentralised and the Mutual Recognition Procedures), intermediate procedural steps are hardly challengeable at any level: firstly, because of the strict duality of jurisdiction, and the fact that the systems of judicial review are not geared towards the multi-level nature of decision-making. Secondly, the gaps of judicial protection arise due to the hybridity of certain bodies involved in the process (this is the case with the $\mathrm{CMDh}$, whose actions are not reviewable at national level and may not be reviewable at EU level).

These challenges are systemic in the composite nature of EU administration and difficult to address. One ideal improvement would be the introduction of horizontal and reverse preliminary ruling systems. In this way the court of the measure which concludes the process could ask a question of validity to the courts of the system of the intermediate measures. Such a system of preliminary rulings would allow for validity questions to be dealt with by the judicial system in which the measures originate, which would address the concern that judicial review of preparatory measures in composite procedures is inconceivable due to the extraterritorial effects and problems in enforcement of such decisions. ${ }^{94}$ One could also question whether national courts should disregard the orthodox territoriality principle which prevents them from reviewing foreign administrative action, and should be put in a position where they are able to review measures originating in other Member States' administration, regarding their validity under EU law. ${ }^{95}$ However, this possibility would create serious legal certainty problems, as the foreign can certainly not be annulled by the courts of another legal system, but, at most, set aside inter partes. For this reason, albeit rather implausible for political reasons, a system of horizontal preliminary rulings would be preferable if the system of judicial protection is to become "integrated" as the system of administrative decision-making.

\footnotetext{
94 On this problem of extraterritoriality see also Opinion of AG Bobek in Astellas Pharma Gmbh, supra, note 13, paras 83 and 94.

95 Evidence that this process is taking place already is scattered and difficult to collect, but nevertheless exists. See the Forabosco case, in which the French Council of State declared itself competent to review a measure, issued in the context of the Schengen Information System, originating from the German authorities: judgment of 9 June 1999, no 190384.
} 